\title{
Pengaruh Budaya dan Iklim Organisasi Terhadap Kinerja Melalui Komitmen Organisasional Dan Motivasi Kerja Pegawai Pada Dinas Pekerjaan Umum Provinsi Maluku
}

\author{
Tehubijuluw Zacharias' \\ 1Fisip, Universitas Kristen Indonesia Maluku. E-mail: tehubijuluwtjak@yahoo.co.id
}

ARTICLE INFO

Keywords: policy network, policy formulation, policy actor

Kata kunci: budaya, iklim organisasi, komitmen organisasional, motivasi kerja, kinerja

How to cite:

Zacharias (2019).

Pengaruh Budaya dan

Iklim Organisasi

Terhadap Kinerja

Melalui Komitmen

Organisasional dan

Motivasional Kerja

Pegawai Pada Dinas

Pekerjaan Umum

Provinis Maluku.

JAKPP (Jurnal Analisis

Kebijakan dan Pelayanan

Publik), 1-14.

\section{ABSTRACT}

This study aims to determine the effect of culture and organizational climate on performance through organizational commitment and motivation of employee work at the Public Works Office of Maluku Province. The approach used in this study is a quantitative approach (positivist). The research location is the Maluku Provincial Public Works Agency. A sample of 149 people was determined by simple random sampling. The data analysis method used in this study is Generalized structured component analysis (GSCA). The results showed that organizational culture and climate had a significant positive effect both directly and indirectly on performance through organizational commitment and employee motivation at the Maluku Provincial Public Works Agency.

Abstrak

Penelitian ini bertujuan untuk mengetahui pengaruh budaya dan iklim organisasi terhadap kinerja melalui komitmen organisasional dan motivasi kerja pegawai pada Dinas Pekerjaan Umum Provinsi Maluku. Pendekatan yang digunakan dalam penelitian ini adalah pendekatan kuantitatif (positivism). Lokasi penelitian adalah Dinas Pekerjaan Umum Provinsi Maluku. Sampel sebanyak 149 orang yang ditentukan secara acak sederhana. Metode analisis data yang digunakan dalam penelitian ini adalah Generalized structured component analysis (GSCA). Hasil penelitian menunjukkan bahwa budaya dan iklim organisasi berpengaruh positif signifikan baik secara langsung maupun secara tidak langsung terhadap kinerja melalui komitmen organisasional dan motivasi kerja pegawai pada Dinas Pekerjaan Umum Provinsi Maluku.

Copyright (C) 2019 JAKPP. All rights reserved.

\section{Pendahuluan}

Salah satu masalah nasional yang dihadapi oleh bangsa Indonesia saat ini adalah penanganan terhadap rendahnya kualitas sumber daya manusia. Jumlah sumber daya manusia yang besar apabila digunakan secara efektif dan efisien, hal ini akan bermanfaat untuk menunjang gerak lajunya pembangunan nasional yang 
berkelanjutan. Melimpahnya sumber daya manusia yang ada saat ini mengharuskan berfikir secara seksama yaitu bagaimana dapat memanfaatkan sumber daya manusia secara optimal.Agar di masyarakat memiliki sumber daya manusia yang handal, maka diperlukan pendidikan yang berkualitas, penyediaan berbagai fasilitas sosial, lapangan pekerjaan yang memadai. Kelemahan dalam penyediaan berbagai fasilitas tersebut akan menyebabkan keresahan sosial yang akan berdampak kepada keamanan masyarakat. Saat ini kemampuan sumber daya manusia masih rendah baik dilihat dari kemampuan intelektualnya maupun keterampilan teknis yang dimilikinya (Koesmono, 2005).

Hubungan budaya organisasi dengan kinerja telah diteliti oleh peneliti sebelumnya, Lee dan Yu (2004) melakukan penelitian pada perusahaan di Singapura, hasil penelitian menunjukkan bahwa kekuatan budaya organisasi berhubungan dengan kinerja. O'Regan dan Ghobadian (2004), meneliti hubungan budaya organisasi dengan kinerja, hasil penelitian menunjukkan bahwa budaya organisasi yang kuat memiliki hubungan terhadap kinerja jangka panjang. Chen (2004), melakukan penelitian pada perusahaan manufaktur di Taiwan, hasil penelitian budaya organisasi berpengaruh signifikan dan positif terhadap kepuasan, akan tetapi tidak berpengaruh signifikan terhadap kinerja.

Hasil penelitian terdahulu yang dilakukan Lee dan Yu (2004), O'Regan dan Ghobadian (2004) menunjukkan bahwa budaya organisasi berhubungan dengan kinerja. Sedangkan penelitian yang dilakukan Chen (2004), hasil penelitiannya berbeda yaitu budaya organisasi berpengaruh tidak signifikan terhadap kinerja, Perbedaan hasil penelitian merupakan peluang untuk melakukan pengujian kembali hubungan antara budaya organisasi dengan kinerja.

Iklim organisasi dapat mempengaruhi kinerja, hal ini telah dilakukan oleh peneliti terdahulu, West (2000) berpendapat bahwa iklim organisasi merujuk pada berfungsinya organisasi secara keseluruhan dari sudut pandang para karyawan. Ini adalah jawaban atas pertanyaan "bagaimana rasanya bekerja di sini?", dengan demikian, iklim organisasi adalah suatu metafora yang menggambarkan persepsi karyawan secara individual mengenai lingkungan organisasi mereka, suatu persepsi yang dapat mempengaruhi motivasi, inovasi dan kinerja mereka.

Hubungan antara budaya organisasi dengan komitmen organisasional telah dilakukan oleh peneliti sebelumnya, Wu (2000), melakukan penelitian di Taiwan, budaya organisasi berhubungan penting terhadap komitmen organisasi karyawan. Lock et al., (2011), meneliti budaya organisasi pada organisasi kesehatan, budaya inovatif berpengaruh terhadap komitmen, sedangkan budaya birokrasi tidak berpengaruh terhadap komitmen. Kamaliah (2012), pengaruh budaya organisasi terhadap komitmen organisasional, budaya organisasi tidak berpengaruh signifikan terhadap komitmen organisasional.

Hasil penelitian terdahulu menunjukkan adanya hasil yang berbeda, penelitian $\mathrm{Wu}$ (2000) dan Lock et al., (2011), budaya organisasi berhubungan dengan komitmen. Sedangkan Kamaliah (2012), budaya organisasi tidak berpengaruh terhadap komitmen. Hasil penelitian terdahulu menunjukkan bahwa budaya organisasi tidak selalu memiliki pengaruh terhadap komitmen, sehingga 
perlu untuk dilakukan pengujian kembali pengaruh budaya organisasi terhadap komitmen.

Penelitian Chen et al., (2006), Yousef (2000), Kohtamäki et al., (2012), Suliman dan Al Kathairi (2013), komitmen organisasional berpengaruh terhadap kinerja. Sedangkan penelitian yang dilakukan Lee et al., (2010), Shaw et al., (2003), Yiing dan Achmad (2009), hasil penelitian menunjukkan komitmen tidak berpengaruh terhadap kinerja. Hasil penelitian yang berbeda menunjukkan bahwa komitmen yang dimiliki pegawai pada organisasi belum tentu menghasilkan kinerja.Hasil penelitian terdahulu yang berbeda tersebut menjadi peluang untuk menguji kembali pengaruh komitmen organisasional terhadap kinerja.

Penelitan terdahulu juga telah mengkaitkan iklim organisasi dengan motivasi, Yun dan Chuan (2012), iklim organisasi berpengaruh terhadap motivasi, dan motivasi sebagai moderasi iklim organisasi terhadap inovasi. Suliman dan Abdulan (2005), iklim organisasi berhubungan dengan motivasi. Prabhjot (2009), iklim organisasi merupakan variabelpenting untukmembangkitkan motivasiantara karyawan.Tyagi (1982), iklim organisasi secara keseluruhan berpengaruh terhadap motivasi interinsik, dan tidak berpengaruh terhadap motivasi eksterinsik.

Hubungan antara motivasi kerja dengan kinerja telah dilakukan oleh peneliti sebelumnya, Arshadi (2010), motivasi kerja berkorelasi dengan kinerja. Güngör (2011), motivasi kerja berpengaruh signifikan terhadap kinerja karyawan, dan motivasi sebagai mediasi hubungan antara sistem imbalan manajemen terhadap kinerja karyawan. Susan et al., (2012), motivasi kerja berpengaruh signifikan terhadap kinerja. Campbell (2007), motivasi interinsik tidak berpengaruh terhadap kinerja, sedangkan motivasi eksterinsik berpengaruh terhadap kinerja. Miao et al., (2007), motivasi interinsik berpengaruh signifikan terhadap kinerja, sedangkan motivasi eksterinsik berpengaruh tidak signifikan terhadap kinerja.

Berdasarkan kajian empiris dan beberapa kajian teori sebelumnya maka penelitian ini bertujuan untuk mengetahui pengaruh pengaruh budaya dan iklim organisasi terhadap kinerja melalui komitmen organisasional dan motivasi kerja pegawai pada Dinas Pekerjaan Umum Provinsi Maluku.

\section{Kajian Literatur}

Salah satu elemen yang mempengaruhi perilaku karyawan adalah lingkungan dari karyawan itu sendiri, yang dalam hal ini budaya perusahaan yang melingkupinya. Sebagai mahluk sosial, karyawan tidak terlepas dari berbagai nilai dan norma yang ada di perusahaan. Budaya organisasi dapat mempengaruhi cara karyawan bertingkah laku, cara menggambarkan pekerjaannya, cara bekerja dengan koleganya, dan cara memandang masa depan dengan wawasan yang luas ditentukan oleh norma, nilai dan kepercayaannya. Gibson (1997) menyatakan budaya organisasi menentukan apa yang boleh dan tidak boleh dilakukan oleh anggota organisasi, menentukan batas - batas normatif perilaku anggota organisasi, menentukan sifat dan bentuk pengendalian dan 
pengawasan organisasi, menentukan gaya manajerial yang dapat diterima oleh anggota organisasi, menentukan cara kerja yang tepat dan lain sebagainya.

Kotter dan Heskett (1997) mengatakan bahwa budaya yang kuat dapat menghasilkan efek yang sangat mempengaruhi individu dan kinerja, bahkan dalam suatu lingkungan bersaing pengaruh tersebut dapat lebih besar daripada faktor-faktor lain. Penelitian lain juga menyatakan bahwa pengaruh budaya organisasi terhadap kinerja pegawai memiliki hubungan yang kuat (Mulyadi, Sulaeman, dan Ramadhani, 2012). Sebaliknya Kotter dan Heskett (1992) mendapatkan suatu kenyataan bahwa budaya perusahaan yang mudah menyesuaikan dengan perubahan jaman (adaptif) adalah yang dapat meningkatkan kinerja. Budaya organisasi berpengaruh langsung terhadap kinerja karyawan, dimana dengan penerapan budaya organisasi yang baik mampu mendorong karyawan untuk bekerja lebih baik. Dengan budaya kerja yang tepat waktu, bertanggung jawab pada pekerjaannya dan selalu berorientasi pada pelanggan mampu meningkatkan kinerjanya. Hal tersebut didukung oleh Kotter dan Heskett (1992), yang menyatakan bahwa pengelolaan yang baik atas budaya organisasi dapat mempengaruhi tercapainya kinerja karyawan yang tinggi.

\section{Metode Penelitian}

Pendekatan yang digunakan dalam penelitian ini adalah pendekatan kuantitatif (positivism). Berdasarkan tujuan yang ingin dicapai dan sifat hubungan atar variabel, maka penelitian ini termasuk penelitian explanatory research dengan pengumpulan data dilakukan sekaligus dalam satu tahap (one shot study) atau secara cross-section melalui kuisioner. Lokasi penelitian adalah Dinas Pekerjaan Umum (PU) Provinsi Maluku. Sampel sebanyak 149 orang yang ditentukan secara acak sederhana. Metode analisis data yang digunakan dalam penelitian ini adalah Generalized structured component analysis (GSCA). Generalized structured component analysis (GSCA) adalah metode baru Structural Equation Modeling (SEM) berbasis komponen, sangat penting dan dapat digunakan untuk perhitungan skor (bukan skala) dan juga dapat diterapkan pada sampel yang sangat kecil. GSCA juga dapat digunakan pada model structural yang melibatkan variabel dengan indikator refleksif dan atau formatif (Solimun, 2012).

\section{Hasil dan Pembahasan}

\section{Hasil Penelitian}

Konstruk pada teknik SEM disebut dengan latent variable (variabel yang tidak dapat diukur secara langsung) dan indikatornya adalah observed variable (variabel yang diamati, sebagai operasionalisasi pengukuran atas variabel laten). Setelah susunan konstruk dan indikatornya dinyatakan dalam model, kemudian dilakukan uji validitas dan reliabilitas. 
Pengujian model bertujuan untuk melihat kesesuaian model.Adapun hasil pengujian kesesuaian model dalam penelitian ini adalah seperti terlihat dalam Tabel 1 :

Tabel 1

Indeks Kesesuaian Model

\begin{tabular}{|c|c|c|c|}
\hline Kriteria & Nilai Cut-Off & $\begin{array}{c}\text { Hasil } \\
\text { Perhitungan }\end{array}$ & Keterangan \\
\hline Chi-Square & Diharapkan kecil & 38,39 & $\mathrm{X}^{2}$ sebesar 86,39 \\
\hline $\begin{array}{c}\text { Significance } \\
\text { Probability }\end{array}$ & $\leq 0,05$ & 0,001 & Baik \\
\hline RMSEA & $\leq 0,08$ & 0,032 & Baik \\
\hline GFI & $\geq 0,90$ & 0,97 & Baik \\
\hline AGFI & $\geq 0,90$ & 0,94 & Baik \\
\hline NFI & $\geq 0,95$ & 0,96 & Baik \\
\hline CFI & $\geq 0,95$ & 0,99 & Baik \\
\hline
\end{tabular}

Sumber : Data Primer Setelah Diolah, 2017

Tabel 1 menunjukkan bahwa tujuh kriteria yang digunakan untuk menilai layak / tidaknya suatu model ternyata semua kriteria terpenuhi, dengan demikian tidak perlu dilakukan modifikasi. Hal ini dapat dikatakan bahwa model dapat diterima, yang berarti ada kesesuaian antara model dengan data.

Hasil estimasi model structural dapat dilihat pada gambar diagram lintasan basic model T-Values sebagaimana berikut ini :

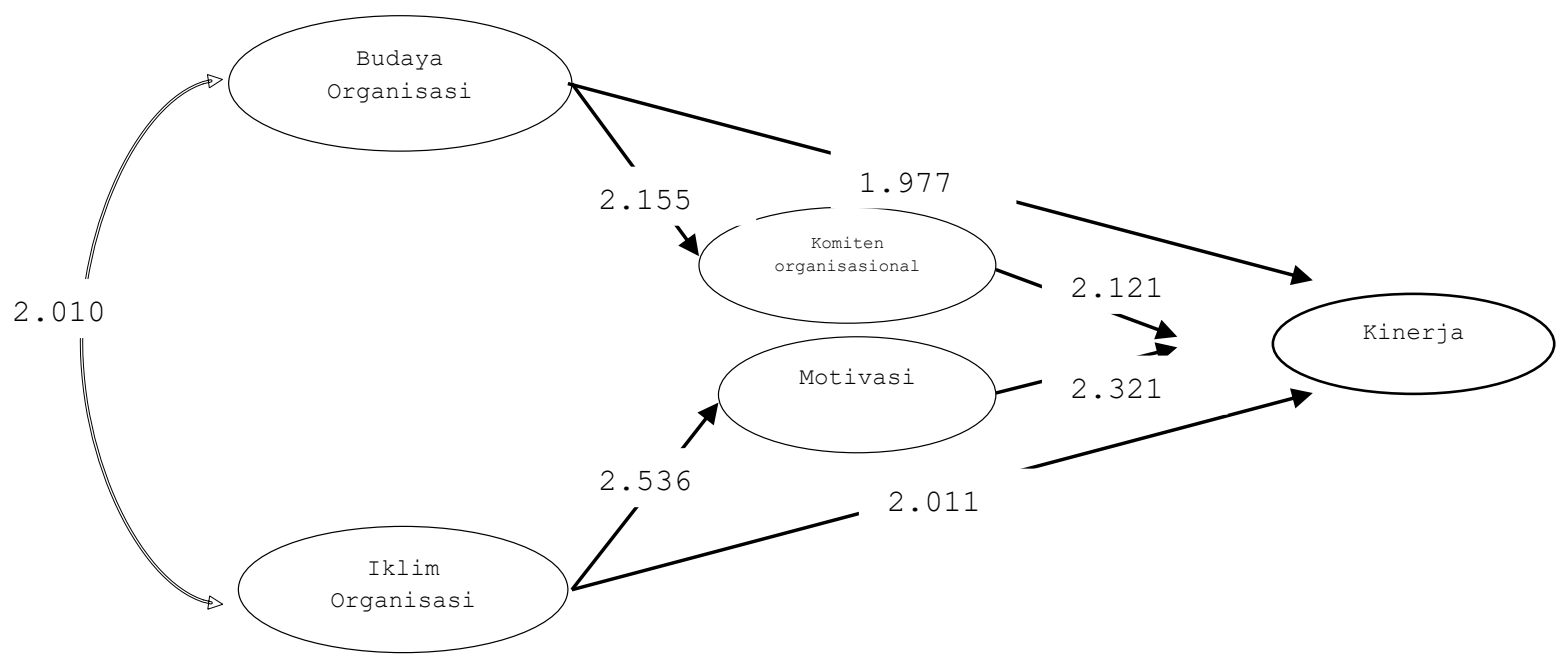

Gambar 1

Model T-Value Pengaruh Budaya dan Iklim Organisasi Terhadap Kinerja Melalui Komitmen Organisasional dan Motivasi

Nilai T-value masing-masing jalur menunjukkan nilai >1,96 yang menunjukkan bahwa pengaruh variabel eksogen terhadap variabel endogen 
adalah signifikan. Adapun diagram lintasan basic model - standardized solution dapat dilihat pada gambar 2 berikut ini :

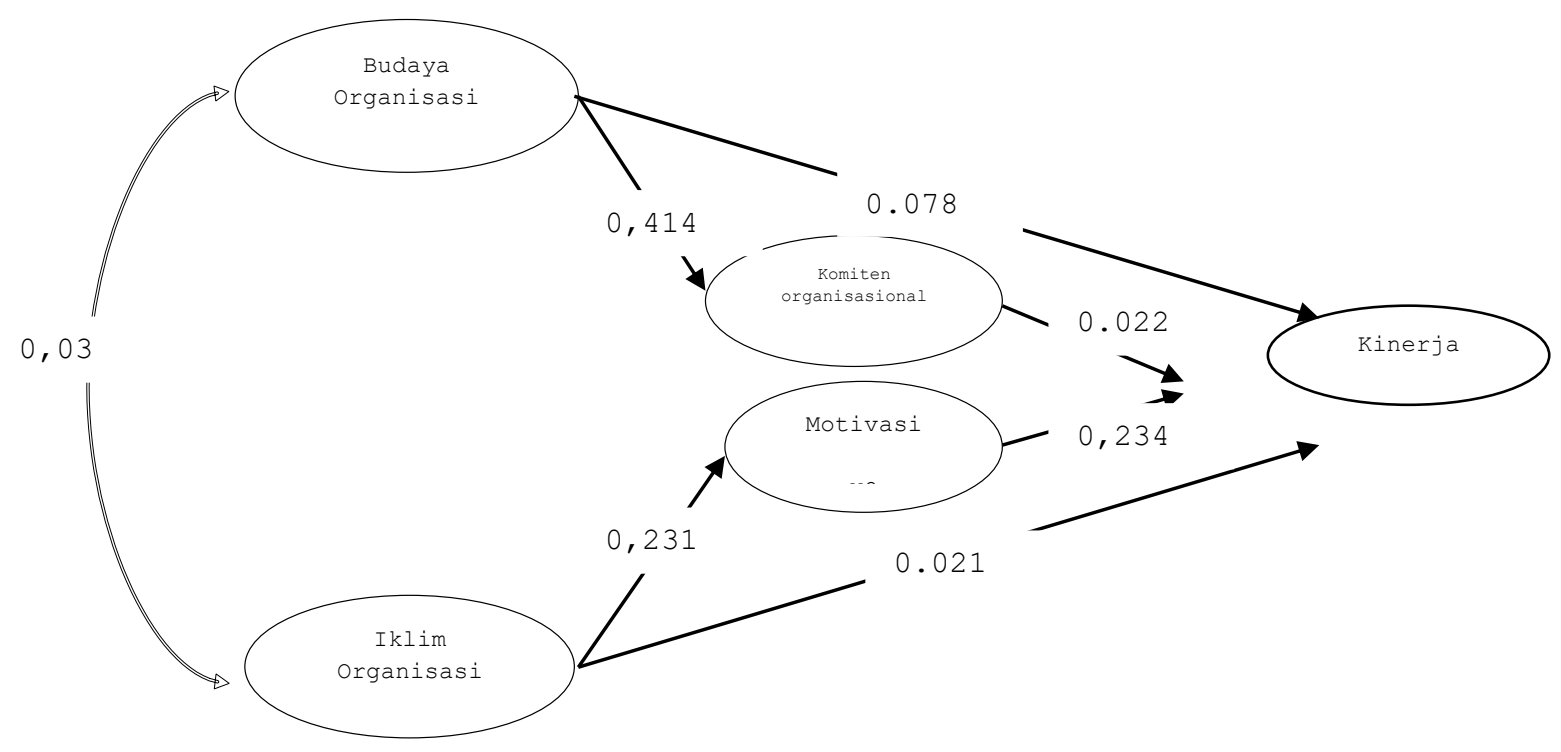

Gambar 2.

Model Struktural Pengaruh Budaya dan Iklim Organisasi Terhadap Kinerja Melalui Komitmen Organisasional dan Motivasi

Berdasarkan kedua model di atas, maka dapat di interpretasikan masing-masing koefisien jalur. Penyajian koefisien jalur secara rinci disajikan pada Tabel 2 :

Tabel 2

Hasil Analisis Pengaruh langsung

\begin{tabular}{|l|c|c|c|}
\hline \multicolumn{1}{|c|}{ Struktur Hubungan } & Koefisien & $\begin{array}{c}\mathbf{P} \\
\text { Value }\end{array}$ & Ket. \\
\hline Budaya Organisasi $\longrightarrow$ Kinerja & 0,078 & 0,056 & Sig. \\
Budaya organisasi $\longrightarrow$ Komitmen organisasional & 0,414 & 0,001 & Sig. \\
Iklim Organisasi $\longrightarrow$ Kinerja & 0,021 & 0,000 & Sig. \\
Iklim Organisasi $\longrightarrow$ Motivasi & 0,231 & 0,001 & Sig. \\
Komitmen Organisasional $\longrightarrow$ Kinerja & 0,022 & 0,001 & Sig. \\
Motivasi $\longrightarrow$ Kinerja & 0,234 & 0,001 & Sig. \\
\hline
\end{tabular}

Sumber : Data Primer Setelah Diolah, 2017

Pengaruh langsung (direct effect) merupakan pengaruh dari satu variabel bebas ke satu variabel terikat, atau dalam model path digambarkan dengan satu anak panah. Sedangkan jalur tidak langsung melalui satu variabel intervening atau variabel antara. Variabel intervening atau dalam terminologi disebut variabel kontrol yaitu variabel yang memiliki kemampuan untuk merubah arah, koefisien maupun tingkat signifikan dari suatu pengaruh atau hubungan ketika ada satu atau lebih variabel yang dimasukkan dalam model. 
Berdasarkan hubungan kausalitas dan model struktural, dapat diketahui pengaruh tidak langsung (indirect effect) antar variabel yang dianalisis. Untuk lebih jelasnya dapat dilihat pada tabel berikut :

Tabel 3

Hasil Analisis Pengaruh Tidak Langsung

\begin{tabular}{|l|l|l|}
\hline \multicolumn{1}{|c|}{ No } & \multicolumn{1}{|c|}{ Indirect Effect } & \multicolumn{1}{|c|}{ Nilai } \\
\hline 1 & Pengaruh tak langsung X1 terhadap Y3 melalui Y1 & 0,211 \\
\hline 2 & Pengaruh tak langsung X2 terhadap Y3 melalui Y2 & 0,728 \\
\hline
\end{tabular}

Sumber : Data Primer Setelah Diolah, 2017

Pengaruh tidak langsung, diketahui bahwa :

1. Pengaruh budaya organisasi terhadap kinerja karyawan melalui komitmen organisasional sebesar 0,211, sehingga dapat dikatakan bahwa komitmen organisasional sebagai variabel intervening bersifat menguatkan.

2. Pengaruh iklim organisasi terhadap kinerja karyawan melalui motivasi sebesar 0,728, sehingga dapat dikatakan bahwa motivasi sebagai variabel intervening bersifat menguatkan.

\section{Pembahasan}

\section{Pengaruh Budaya Organisasi terhadap Komitmen Organisasional}

Hasil perhitungan menunjukkan bahwa budaya organisasi $\left(X_{1}\right)$ berpengaruh positif dan signifikan terhadap komitmen organisasional $\left(\mathrm{Y}_{1}\right)$. Hal ini terlihat dari koefisien jalur yang bertanda positif sebesar 0,414 dengan nilai $\mathrm{t}$ value 2,155 >1,96. Dengan demikian hipotesis penelitian yang menyatakan bahwa budaya organisasi berpengaruh signifikan terhadap komitmen organisasional terbukti.

Budaya organisasi dalam penelitian ini diukur dengan indikator pemberdayaan karyawan, orientasi tim, visi, kejelasan arah dan tujuan perusahaan. Budaya organisasi pada Dinas PU Provinsi Maluku menjadi asumsi dasar dan tata cara befikir untuk melakukan sesuatu yang mentradisi bersama oleh semua anggota organisasi.

Hal ini sejalan dengan pendapat Hofsted dalam Koesmono (2005), bahwa budaya merupakan interaksi dari ciri-ciri kebiasaan yang mempengaruhi kelompok orang dalam lingkungannya. Demikian pula Eldrige \& Crombi (2007), budaya organisasi sebagai konfigurasi unik dari norma, nilai, kepercayaan dan cara-cara berperilaku yang memberikan karakteristik cara kelompok dan individu bekerja sama untuk menyelesaikan tugasnya.

Penelitian ini sejalan dengan Muriman, dkk (2008) menyatakan bahwa budaya organisasi berpengaruh besar terhadap kepuasan kerja, jika anggota organisasi merasa puas dalam pekerjaannya, maka perasaan puas tersebut 
diaktualisasikan dalam bentuk komitmen kepada organisasi tersebut. Dan juga pentingnya komitmen organisasi ini dimiliki oleh anggota organisasi, karena dengan anggota memiliki komitmen yang tinggi terhadap organisasi maka akan termotivasi dan lebih puas terhadap pekerjaannya, yang pada umumya meraka menjadi kurang tertarik untuk meninggalkan organisasi mereka.

\section{Pengaruh Budaya Organisasi terhadap Kinerja}

Hasil perhitungan menunjukkan bahwa budaya organisasi berpengaruh positif signifikan terhadap kinerja karyawan. Hal ini terlihat dari koefisien jalur yang bertanda positif sebesar 0,078 dengan nilai $t$ value 1,977 > 1,96. Dengan demikian hipotesis penelitian yang menyatakan bahwa budaya organisasi berpengaruh signifikan terhadap kinerja terbukti.

Hasil penelitian sejalan dengan yang ditunjukkan oleh Zunaidah et.al (2014:52) yaitu variabel budaya organisasi mempunyai $t$ hitung sebesar 6.550 dengan tingkat signifikansi sebesar 0.000 yang lebih kecil dari a $(0.000<0.050)$, H0 ditolak, hal ini berartikan bahwa budaya organisasi berpengaruh signifikan terhadap kinerja karyawan. Penelitian oleh Widodo (2011:78) juga menunjukkan hasil yang sama, budaya berpengaruh positif dan signifikan terhadap kinerja dengan tingkat korelasi sebesar 0,808 dan tingkat signifikansi sebesar 0,005 < 0,05. Demikian pula dengan hasil penelitian yang dilakukan oleh Koesmono (2005:175) menunjukkan bahwa budaya organisasi berpengaruh terhadap kinerja karyawan secara positif. Guntur (2012) komitmen organisasional terjadi apabila karyawan ingin menjadi bagian dari organisasi karena memang ingin melakukannya. Hal ini bias mempengaruhi perawat untuk tetap mengabdikan diri pada rumah sakit dengan cara meningkatkan kinerjanya.

Penelitian ini berbeda dengan penelitian sebelumnya diantaranya adalah penelitian yang dilakukan oleh Pastian et.al (2013:15) menunjukkan bahwa budaya organisasi tidak berpengaruh signifikan terhadap kinerja pegawai Sekretariat Daerah Kota Sungai Penuh dengan koefisien regresi sebesar 0,012 dengan nilai Critical Ratio sebesar 0,146.

\section{Pengaruh Iklim Organisasi terhadap Motivasi}

Hasil perhitungan menunjukkan bahwa iklim organisasi berpengaruh positif signifikan terhadap motivasi karyawan. Hal ini terlihat dari koefisien jalur yang bertanda positif sebesar 0,231 dengan nilai $t$ value 2,536 $>1,96$. Dengan demikian hipotesis penelitian yang menyatakan bahwa iklim organisasi berpengaruh signifikan terhadap motivasi karyawan terbukti.

Penelitian ini sejalan dengan pendapat Gellerman (1963: 67) menyatakan bahwa orang yang mempunyai motivasi berprestasi tinggi akan sangat senang kalau ia berhasil memenangkan suatu persaingan. Ia berani menanggung segala resiko sebagai konsekwensi dari usahanya untuk mencapai tujuan.

Penelitian ini sejalan dengan temuan Safrijal (2014) bahwa hasil analisis jalur $\rho \times 3 \times 2$ diketahui mempunyai koefisien jalur sebesar 0,500; nilai koefisien jalur ini juga menunjukkan besarnya pengaruh iklim organisasi terhadap motivasi kerja yaitu sebesar 50\%. Temuan penelitian menunjukkan secara langsung iklim organisasi berpengaruh terhadap motivasi kerja, artinya semakin baik iklim organisasi dalam suatu organisasi maka akan meningkatkan motivasi kerja 
karyawannya dalam hal ini motivasi kerja dosen di STIKes Cut Nyak Dhien Langsa.

\section{Pengaruh Iklim Organisasi terhadap Kinerja}

Hasil perhitungan menunjukkan bahwa iklim organisasi berpengaruh positif signifikan terhadap kinerja karyawan. Hal ini terlihat dari koefisien jalur yang bertanda positif sebesar 0,021 dengan nilai $t$ value 2,011 > 1,96. Dengan demikian hipotesis penelitian yang menyatakan bahwa iklim organisasi berpengaruh signifikan terhadap kinerja karyawan terbukti.

Iklim organisasi yang baik yaitu suasana yang mampu memberikan kenyamanan kepada pelaksananya yang muaranya akan meningkatkan kinerja. Menurut Husaini (2008 : 197) iklim organisasi ialah seperangkat karakteristik yang dimiliki organisasi yang mempengaruhi anggotanya. Lebih lanjut beliau menambahkan iklim organisasi merupakan suasana kerja yang dialami oleh anggota organisasi misalnya lewat ruang kerja yang menyenangkan, rasa aman dalam bekerja, penerangan yang memadai, sarana dan prasarana yang memadai, jaminan sosial yang memadai, promosi, jabatan, kedudukan, pengawasan yang memadai, dan lain-lain.

Penelitian ini sejalan dengan temuan Safrijal (2014) bahwa analisis jalur

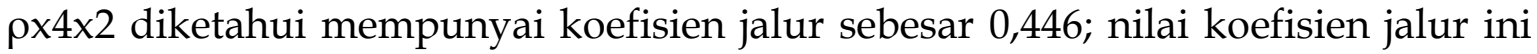
juga menunjukkan besarnya pengaruh iklim organisasi terhadap kinerja dosen yaitu sebesar 44,6\%. Hasil penelitian menunjukkan bahwa iklim organisasi secara langsung mempengaruhi kinerja dosen, artinya jika iklim organisasi baik maka dengan sendirinya akan dapat memperngaruhi kinerja pekerja.

Sejalan juga dengan pendapat Safrijal (2014) bahwa besarnya pengaruh tidak langsung iklim organisasi terhadap kinerja dosen melalui motivasi kerja yaitu sebesar $12,3 \%$. Temuan penelitian menunjukkan bahwa iklim organisasi secara tidak langsung mempengaruhi kinerja dosen melalui motivasi kerja, artinya dengan iklim organisasi yang baik maka para dosen akan termotivasi dalam berkerja yang pada akhirnya akan mempengaruhi kinerja dalam melakukan pekerjaannya.

Iklim organisasi sebagai koleksi dan pola lingkungan yang menentukan munculnya motivasi serta berfokus pada persepsi-persepsi yang masuk akal atau dapat dinilai, sehingga mempunyai pengaruh langsung terhadap kinerja anggota organisasi.Iklim organisasi adalah kondisi lingkungan kerja, baik yang bersifat material/ fisik maupun non material/ non fisik yang dapat mempengaruhi perilaku/ kinerja karyawan di dalam suatu organisasi.

\section{Pengaruh Budaya Organisasi terhadap Kinerja Melalui Mediasi Komitmen Organisasional}

Hasil perhitungan menunjukkan bahwa budaya organisasi berpengaruh positif signifikan terhadap kinerja karyawan melalui mediasi komitmen organisasional. Hal ini terlihat dari koefisien jalur yang bertanda positif sebesar 
0,221 dengan nilai $t$ value 1,977 > 1,96. Dengan demikian hipotesis penelitian yang menyatakan bahwa budaya organisasi berpengaruh signifikan terhadap kinerja melalui mediasi komitmen organisasional, terbukti.

Hasil penelitian ini menunjukkan bahwa peningkatan kinerja pegawai dapat dilakukan dengan perbaikan budaya organisasi yang dapat meningkatkan komitmen karyawan terhadap organisasi, baik komitmen afektif maupun komitmen keberlanjutan. Hal ini sejalan dengan penelitian Sopiah (2008) yang menyimpulkan bahwa bahwa pemahaman tentang pengaruh budaya organisasi secara positif dan signifikan terhadap kinerja karyawan adalah bahwa semakin baik budaya organisasi yang dibangun maka meningkat pula tingkat kepuasan kerja karyawan dan kepuasan kerja karyawan dipengaruhi oleh komitmen organisasional pimpinan yang kemudian akan berdampak pada peningkatan kinerja.

Robins (2008) menyebutkan bahwa proses proses penciptaan budaya terjadi dalam tiga cara. Pertama, para pendiri hanya mempekerjakan dan mempertahankan karyawan yang berpikir dan merasakan cara yang mereka tempuh. Kedua, mereka mengindoktrinasikan dan mensosialisasikan karyawan ini dengan cara berpikir dan cara berperasaan mereka. Dan ahirnya perilaku pendiri itu sendiri bertindak sebagai model peran yang mendorong karyawan mengindentifikasikan diri dengan mereka dan oleh karenanya menginternalisasikan keyakinan, nilai, dan asumsi-asumsi meraka.Bila organisasi berhasil, visi pendiri menjadi terlihat sebagai penentu utama keberhasilan.Pada titik ini keseluruhan kepribadian pendiri menjadi tertanam ke dalam budaya organisasi. Budaya organisasi ini, sebagai sekumpulan asumsi-asumsi mendasar, berfungsi untuk memberikan arah bagi anggota organisasi tentang apa yang harus diperhatikan, makna dari segala sesuatu yang harus dicapai, bagaimana seharusnya reaksi dan tindakan yang diambil dalam situasi-situasi tertentu Muriman, dkk (2008).

\section{Pengaruh Iklim Organisasi terhadap Kinerja Melalui Mediasi Motivasi Kerja}

Hasil perhitungan menunjukkan bahwa iklim organisasi berpengaruh positif signifikan terhadap kinerja karyawan melalui mediasi motivasi kerja. Hal ini terlihat dari koefisien jalur yang bertanda positif sebesar 0,728 dengan nilai $\mathrm{t}$ value $1,988>1,96$. Dengan demikian hipotesis penelitian yang menyatakan bahwa iklim organisasi berpengaruh signifikan terhadap kinerja melalui mediasi motivasi kerja, terbukti.

Iklim organisasi juga berpengaruh terhadap kinerja melalui variabel moderat motivasi. Suatu kondisi organisasi yang kondusif sangat mempengaruhi kinerjanya.Bahkan berpengaruh terhadap kompetensi, kepuasan kerjanya.Iklim organisasi berhubungan dengan bagaimana karyawan mempersepsikan karakteristik iklim suatu organisasi. Kuatnya suatu iklim organisasi akan berpengaruh terhadap makin meningkatnya mutu informasi serta koordinasi perilaku semua yang terlibat dalam organisasi.

Hasil penelitian ini menunjukkan bahwa motivasi dapat memediasi iklim organisasi dalam meningkatkan kinerja karyawan. Setiap orang dalam beraktivitas berbeda antar yang satu dengan yang lainnya bergantung kepada 
kemampuan, kemauan, keinginan, harapan, kebutuhan, tujuan, sasaran, dan sebagainya.Motivasi juga merupakan suatu kondisi yang memberi dorongan untuk melakukan sesuatu. Karyawan yang mempunyai motivasi kerja yang tinggi akan senantiasa bekerja keras untuk mengatasi segala jenis permasalahan yang dihadapi dengan harapan mencapai hasil yang lebih baik lagi. Hal tersebut tampak pada motivasi kerja yang tinggi, memperlihatkan minat, mempunyai perhatian, dan ikut serta dalam suatu tugas atau kegiatan

Hal ini sejalan dengan pendapat Siagian (1986) bahwa iklim organisasi yang kondusif diperlukan bagi anggota organisasi untuk beraktivitas dalam pencapaian tujuan yang ditetapkan. Pengalaman menunjukkan bahwa suasana kerja yang menggairahkan dapat memotivasi karyawan untuk berbuat lebih banyak bagi organisasi (Siagian,1986). Iklim organisasi yang memadai, bekerja pada tempat yang baik, bersih dan sehat dapat memberikan kepuasan dibandingkan dengan bekerja dalam lingkungan yang kurang memadai (Surya,1994).

\section{Kesimpulan}

1. Budaya organisasi berpengaruh secara langsung terhadap komitmen organisasional sebesar 0,414 dengan nilai t sebesar 2,155 dan berpengaruh secara langsung terhadap kinerja karyawan sebesar 0,078 dengan nilai $t$ sebesar 1,977. Budaya organisasi ini dapat terlihat dari pemberdayaan karyawan, orientasi tim, kejelasan visi, arah dan tujuan perusahaan.

2. Budaya organisasi berpengaruh terhadap kinerja karyawan melalui komitmen organisasional sebesar 0,211, sehingga dapat dikatakan bahwa komitmen organisasional sebagai variabel intervening bersifat menguatkan. Komitmen organisasional dapat terlihat dari karakteristik pekerjaan, karakteristik struktur dan pengalaman kerja.

3. Iklim organisasi berpengaruh secara langsung terhadap motivasi karyawan sebesar 0,231 dengan nilai t sebesar 2,536 dan kinerja karyawan sebesar 0,021 dengan nilai $\mathrm{t}$ sebesar 2,011. Iklim organisasi terlihat dari comformity, responsibility, standard, reward, clarity, team spirit.

4. Iklim organisasi berpengaruh terhadap kinerja karyawan melalui motivasi sebesar 0,728, sehingga dapat dikatakan bahwa motivasi sebagai variabel intervening bersifat menguatkan. Motivasi dapat terlihat dari kebutuhan berprestasi, pengendalian, kebutuhan sosial dan kebutuhan afiliasi.

Berdasarkan kesimpulan di atas, maka disarankan beberapa hal :

1. Dalam membangun budaya organisasi, maka Dinas PU Provinsi Maluku harus tetap memperhatikan nilai-nilai yang terkandung dalam konstruk budaya organisasi yang terdiri dari: pemberdayaan karyawan, orientasi tim, kejelasan visi, arah dan tujuan perusahaan.

2. Peningkatan komitmen organisasi secara teoretis dapat dilakukan dengan: a) memiliki kepercayaan dan menerima tujuan dan nilai organisasi; b) berkeinginan untuk berusahake arah pencapaian tujuan organisasi; dan c) memiliki keinginan yang kuat untuk bertahan sebagai anggota organisasi. 
3. Menciptakan iklim organisasi dengan menerapkan aturan dan kebijakan sehingga semua karyawan merasa bertanggung jawab dalam melaksanakan tugas dan tanggung jawab.

4. Meningkatkan motivasi kerja karyawan dengan memberikan penghargaan yang sesuai dengan hasil kerja.

\section{Daftar Pustaka}

Arshadi Nasrin. 2010. Basic need satisfaction, work motivation, and job performance in an industrial company in Iran. Procedia Social and Behavioral Sciences.Vol. 5, pp 1267-1272

Campbell III James. 2007. Motivation, Attitudes, Goal Setting, Performance and Interactive Effects of Pay for Performance. Dissertation.School of Business \& Technology. Capella University

Chen Jui-Chen, Silverthorne Colin, Hung Jung-Yao. 2006. Organization communication, job stress, organizational commitment, and job performance of accounting professionals in Taiwan and America. Leadership and Organization Development Journal.Vol. 27. Issue 4, pp 242 249

Chen, Li Yuew. 2004. Examining the effect of organizationonal cultured and leadership behavior on organizational commitment, job satisfaction, and job performance at Small and Midlle Sized Firms of Taiwan. Journal of America Academy of Business. Cambridge. September, pp 432 - 438

Gibson J.L, Ivancevich J.M and Donnely J.H. 1997.Organisasi, Jilid 1 dan 2, Edisi kedelapan, Jakarta: Bina.rupa Aksara.

Güngör Pinar. 2011. The Relationship between Reward Management System and Employee Performance with the Mediating Role of Motivation: A Quantitative Study on Global Banks. Procedia Social and Behavioral Sciences.Vol. 24, pp 1510-1520

Kamaliah.2012. Kepemimpinan Transformasional dan Budaya Organisasi Pengaruhnya Terhadap Komitmen Organisasional dan Kinerja Bagian (Studi Pada Bank Syariah di Riau).Disertasi.Pascasarjana Fakultas Ekonomi dan Bisnis. Universitas Brawijaya. Malang.

Koesmono, Teman H. 2005. Pengaruh Budaya Organisasi, Terhadap Motivasi dan Kepuasan Kerja Serta Kinerja Karyawan Pada Sub Sektor Industri 
Pengolahan Kayu Skala Menengah Di Jawa Timur. Jurnal Manajemen $\mathcal{E}$ Kewirausahaan, Vol. 7 No. 2

Kotter, JP dan J.L. Heskett 1997.Corporate Culture and Performance, PT. Prenhallindo. Jakarta

Kotter, John P. and Heskett, james L.. 1992. Corporate Culture and Performance. New York: The Free Press, A Division of Mac Millan, Inc.

Lee, Siew Kim Jean and Yu Kelvin. 2004. Corporate culture and organizational performance. Journal of Management Psychology.Vol. 19.

Lock, Rhodes dan Westwood. 2011. The mediating role of organizational subcultures in health care organizations. Journal of Health Organization and Management. Vol. 25 No. 5

Miao C. Fred, Evans Kenneth R, Zou Shaoming. 2007. The role of salesperson motivation in sales control systems - Intrinsic and extrinsic motivation revisited. Journal of Business Research.Vol. 60, pp 417-425

Mulyadi, D., Sulaeman, E. dan Ramadhani, A. 2012. Pengaruh Budaya Organisasi Terhadap Kinerja Pegawai Pada Dinas Marga dan Pengairan Kabupaten Karawang.Jurnal Manajemen, 9(4).

O'Regan, Nicholas and Ghobadian Abby. 2004. The link between leadership, strategy, and performance in manufacture SMEs, Journal of Small Business Strategy. Vol. 15.Issue.pp $45-57$

Prabhjot Kaur Mahal.2009.Organizational Culture and Organizational Climate as a Determinant of Motivation. The IUP Journal of Management Research, Vol. 4 2 VIII, No. 10, pp 38 - 51

Shaw, Jason D, John E Delery, and Mohamed H.A.A. Abdila. 2003. Organizational Commitment and performance among ques worker and citizens of an Arab Country. Journal Business Research. Vol. 56

Solimun. 2012. Permodelan Persamaan Struktural Generalized Structured Component Analysis GSCA. Modul DIKLAT Aplikasi Statistika Multivariat: GSCA di Fakultas Ekonomi dan Bisnis Universitas Brawijaya Malang Tanggal 26 Mei 2012

Suliman Abubakr M. And Abdulla Mohamed H. 2005. Towards a highperformance workplace: managing corporate climate and conflict. Management Decision. Vol. 43 No. 5, pp. 720-733 
Susan Were M., Gakure R .W, Kiraithe E. K and Waititu A.G. 2012. Influence of Motivation on Performance in the Public Security Sector with a Focus to the Police Force in Nairobi, Kenya.International Journal of Business and Social Science.Vol. 3 No. 23;pp 195 - 204

Tyagi Pradeep K. 1982. Perceived Organizational Climate and the Process of Salesperson Motivation.Journal of Marketing Research.Vol. 2.May.

West, 2000.People and Productivity. New York : McGraw-Hill Book Company.

Wu. W. 2000. Organizational commitment in Taiwanese context: Personal variables, leadership behaviors, corporate culture, and employee commitment. International Graduate Scholl of Management. Australia.

Yousef Darwish A. 2000. Organizational commitment: a mediator of the relationships of leadership behavior with job satisfaction and performance in a non-western country. Journal of Managerial Psychology.Vol. 15. Issue 1, pp $6-28$

Yun Lin Carol Yeh and Chuan Liu Feng. 2012. A cross-level analysis of organizational creativity climate and perceived innovation, The mediating effect of work motivation. European Journal of Innovation Management. Vol. 15 No. 1 , pp. 55-76 